\title{
Business Developments of Nonthermal Solar Technologies
}

\author{
S. A. Smith \\ R. L. Watts \\ T. A. Williams
}

October 1985

Prepared for

Sandia National Laboratories

Under Related Services Agreement

with the U.S. Department of Energy

under Contract DE-AC06-76RLO 1830

Pacific Northwest Laboratory

Operated for the U.S. Department of Energy

by Battelle Memorial Institute 


\title{
DISCLAIMER
}

This report was prepared as an account of work sponsored by an agency of the United States Government. Neither the United States Government nor any agency thereof, nor any of their employees, makes any warranty, express or implied, or assumes any legal liability or responsibility for the accuracy, completeness, or usefulness of any information, apparatus, product, or process disclosed, or represents that its use would not infringe privately owned rights. Reference herein to any specific commercial product, process, or service by trade name, trademark, manufacturer, or otherwise, does not necessarily constitute or imply its endorsement, recommendation, or favoring by the United States Government or any agency thereof. The views and opinions of authors expressed herein do not necessarily state or reflect those of the United States Government or any agency thereof.

\author{
PACIFIC NORTHWEST LABORATORY \\ operated by \\ BATTELLE \\ for the \\ UNITED STATES DEPARTMENT OF ENERGY \\ under Contract DE-AC06-76RLO 1830
}

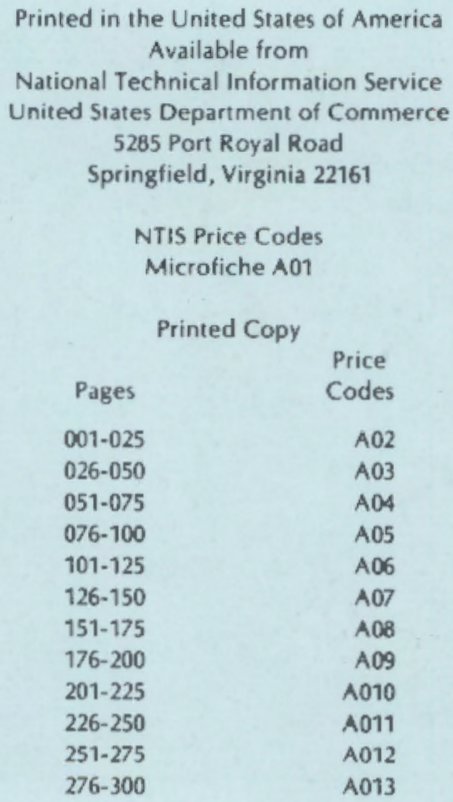


PNL -5628

$U C-62$

BUSINESS DEVELOPMENTS OF

NONTHERMAL SOLAR

TECHNOLOGIES

S. A. Smith

R. L. Watts

T. A. Williams

October 1985

Prepared for

Sandia National Laboratories under a Related Services Agreement with the U.S. Department of Energy under Contract OE-ACO6-76RLO 1830

Pacific Northwest Laboratory

Richland, Washington 99352 

FOREWORD

The research and development described in this document was conducted with in the U.S. Dedartment of Energy's (DOE's) Solar Thermal Technology Program. The goal of the Solar Thermal Technology Program is to advance the engineering and scientific understanding of solar thermal technology and to establish the technologv base from which private industry can develop solar thermal power production options for introduction into the competitive enerqy market.

Solar thermal technology concentrates solar radiation by means of tracking mirrors or lenses onto a receiver where the solar energy is absorbed as heat and converted into electricity or incorporated into products as process heat. The two primary solar thermal technologies, central receivers and distributed receivers, emoloy various point and line-focus ootics to concentrate sunlight. Current cental receiver systems use fields of heliostats (two-ax is tracking mirrors) to focus the sun's radiant energy onto a single tower-mounted receiver. Parabolic dishes up to 17 meters in diameter track the sun in two axes and use mirrors or Fresnel lenses to focus radiant energy onto a receiver. Troughs and bowls are line-focus tracking reflectors that concentrate sunlight onto receiver tubes along their focal lines. Concentrating collector modules can be used alone or in a multimodule system. The concentrated radiant enerqy absorbed by the solar thermal receiver is transported to the conversion process by a circulating working fluid. Receiver temperatures range from $100^{\circ} \mathrm{C}$ in low-temperature troughs to over $1500^{\circ} \mathrm{C}$ in dish and central receiver systems.

The Solar Therma1 Technology Program is directing efforts to advance and improve oromising system concepts through the research and development of solar thermal materials, components, and subsystems, and the testing and performance evaluation of subsystems and systems. These efforts are carried out through the technical direction of DOE and its network of national laboratories, which work with private industry. Together, they have established a comprehensive, goal-directed program to improve performance and provide technically oroven options for eventual incorporation into the nation's energy supply. 
To be successful in contributing to an adequate national energy supply at reasonable cost, solar thermal eneray must eventually be economically competitive with a variety of other energy sources. Components and system-level performance tarqets have been developed as quantitative program goals. The performance targets are used in planning research and development activities, measuring progress, assessing alternative technology options, and developing ontimal components. These targets will be pursued vigorously to insure a successful program.

The objective of this report is to provide information on the commercial developments of wind energy conversion systems (WECS) and photovoltaics (PV) in the U.S. This particular study was conducted because it was felt that the compercial success of these two nonthermal solar technogies has several implications for the future commercial success of solar thermal electric systems. 


\section{SUMMARY}

Pacific Northwest Laboratory (PNL) has examined the business developments of two nonthermal solar technologies in the U.S.: wind energy conversion systems (WECS) and photovoltaics (PV). The installed generating capacities of both the WECS and PV technologies have grown significantly since 1981 .

Currently, more than 550 MW of WECS are installed on wind farms (primarily located in California) and are financed through third-party arranaements. The greatest growth rate has occurred in wind farms of $10 \mathrm{MW}$ to $25 \mathrm{MW}$. Wind system owners contacted as part of this study identified several reasons for ownershio. The primary factors for investing in wind systems were the economic attractiveness of the investment, $1 \mathrm{pw}$ land cost for wind farm development (because the land could also be used for other purposes), ease of permitting, and the ability to use the systems as testing grounds for wind turbine development. While wind systems have experienced some reliability problems (particularly systems installed in the early 1980s), the later systems have proven more reliable, and manufacturers warranties are becoming increasingly available. Some current warranties offer reimbursement of revenue lost while the wind system is not operational.

Bv the end of 1984, approximately 24 MW of PV generating capacity had been installed in the U.S. PV systems range in size from a few watts to more than 6 MW, with most systems ranging from $1 \mathrm{~kW}$ to $999 \mathrm{~kW}$. The largest growth has occurred in systems of $1 \mathrm{MW}$ or larger, increasing from 0 MW in 1981 to more than $8 \mathrm{MW}$ by 1984 . Most PV systems have been financed through third-party arrangements and are owned by industrial (including utility) customers.

PV system owners contacted as part of this study identified several reasons for ownership. The primary factors for investing in PV systems were the economic attractiveness of the investment in the specific application, systems reliability and the ability of the system to operate unattended, the capability of the systems to load follow where demand matches sunlight hours, and the use of the systems for research. The factors that seemed to differ significantly from those described by the wind system owners were the system reliability and the capability of the systems to load follow. 
In their business development to the present, wind and PV systems appear not to have been directly competing in the same markets. Wind system sales have been nearly entirely in third-party owned plants selling energy to a utility. The primary driving force for this development has been that the systems have offered economically attractive returns to investors given the status of the technology and current tax incentives. PV systems have been sold in a wide number of applications, which could best be characterized as small, specialty operations. The PV systems which have been developed for selling eneray to a utility have had research/experimentation more as a driving force than economic attractiveness.

Reliability of both wind and PV systems seems to be a factor that has played an important part in the early commercial development of the technologies. As plants have been installed, a large experience base has developed for investors to judge the reliability of the technologies. Several thousand wind turbines are currently installed, as well as several thousand operating PV systems. The exoerience with the large number of installed turbines seems to have helped improve reliability of the later wind systems. 


\section{CONTENTS}

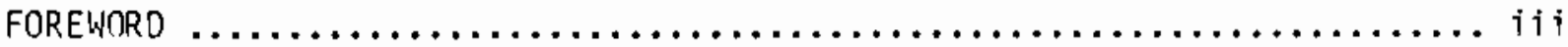

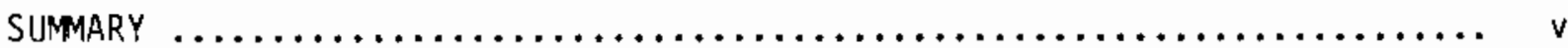

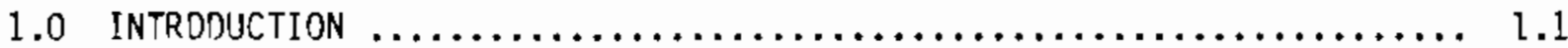

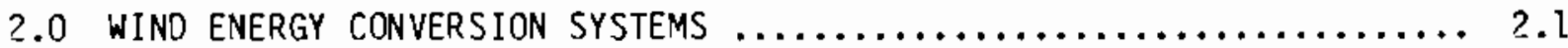

2.1 DATA SOURCES $\ldots \ldots \ldots \ldots \ldots \ldots \ldots \ldots \ldots \ldots \ldots \ldots \ldots \ldots \ldots \ldots \ldots \ldots \ldots \ldots, 2.1$

2.2 WIND TURB INE HISTORY $\ldots \ldots \ldots \ldots \ldots \ldots \ldots \ldots \ldots \ldots \ldots \ldots \ldots, 2.1$

2.3 FEDERAL SUPPORT OF WECS $\ldots \ldots \ldots \ldots \ldots \ldots \ldots \ldots \ldots \ldots \ldots \ldots \ldots \ldots \ldots \ldots \ldots, 2.3$

2.4 WECS CAPACITY $\ldots \ldots \ldots \ldots \ldots \ldots \ldots \ldots \ldots \ldots \ldots \ldots \ldots \ldots \ldots \ldots \ldots \ldots \ldots \ldots \ldots, 2.4$

2.5 FINANCING OF WECS INSTALLATIONS $\ldots \ldots \ldots \ldots \ldots \ldots \ldots \ldots \ldots, 2.7$

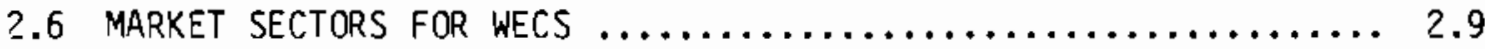

2.7 WECS WARRANTIES $\ldots \ldots \ldots \ldots \ldots \ldots \ldots \ldots \ldots \ldots \ldots \ldots \ldots \ldots \ldots \ldots \ldots \ldots \ldots \ldots, 2.11$

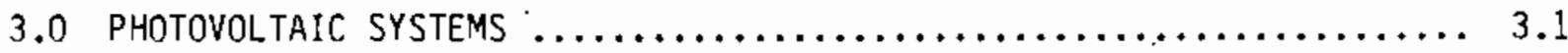

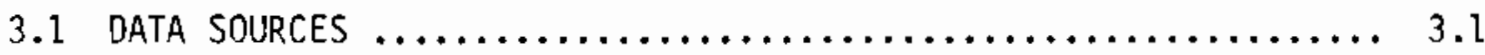

3.2 PV HISTORY $\ldots \ldots \ldots \ldots \ldots \ldots \ldots \ldots \ldots \ldots \ldots \ldots \ldots \ldots \ldots \ldots \ldots \ldots \ldots \ldots, 3.1$

3.3 FEDERAL SUPPORT OF PHOTOVOLTAICS $\ldots \ldots \ldots \ldots \ldots \ldots \ldots \ldots \ldots, 3.2$

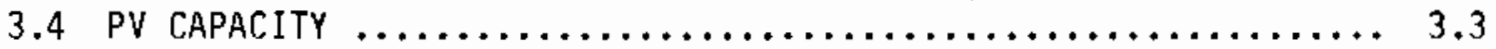

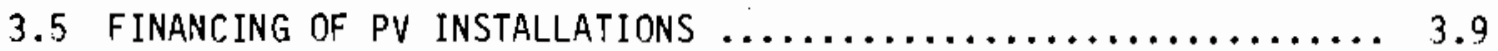

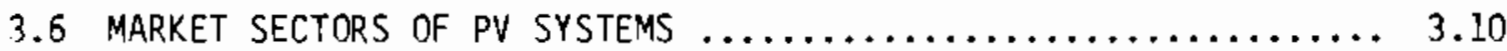

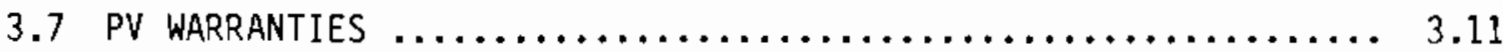

4.0 SALES FACTORS $\ldots \ldots \ldots \ldots \ldots \ldots \ldots \ldots \ldots \ldots \ldots \ldots \ldots \ldots \ldots \ldots \ldots \ldots \ldots \ldots \ldots \ldots \ldots, 1$

4.1 WECS SALES FACTORS $\ldots \ldots \ldots \ldots \ldots \ldots \ldots \ldots \ldots \ldots \ldots \ldots \ldots, 4.2$

4.1 .1 Liberty Wind Park $\ldots \ldots \ldots \ldots \ldots \ldots \ldots \ldots \ldots \ldots \ldots, 4.2$

4.1.2 Flowind Partners $\ldots \ldots \ldots \ldots \ldots \ldots \ldots \ldots \ldots \ldots \ldots \ldots, 4.2$

4.1 .3 Victory Gardens $\ldots \ldots \ldots \ldots \ldots \ldots \ldots \ldots \ldots \ldots \ldots \ldots \ldots \ldots \ldots \ldots \ldots \ldots, 4.3$ 
4.1.4 Buckeye Wind Farms and California Wind Energy Systerns .. 4.3

4.1 .5 Altamont Wind Farm Developers ................ 4.4

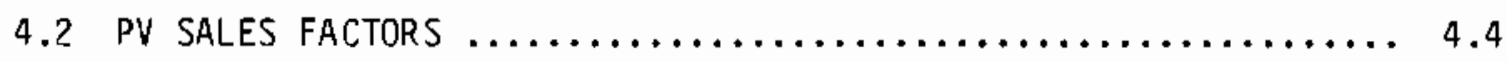

4.2.1 Sacramento Municipal Utility District ............ 4.5

4.2 .2 McDonald's Restaurant .................... 4.5

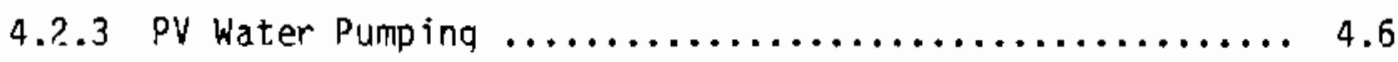

4.2 .4 Georgetown University $\ldots \ldots \ldots \ldots \ldots \ldots \ldots \ldots \ldots \ldots \ldots .6 \ldots$

4.2 .5 Kurt Bleicken $\ldots \ldots \ldots \ldots \ldots \ldots \ldots \ldots \ldots \ldots \ldots \ldots \ldots \ldots \ldots \ldots \ldots$

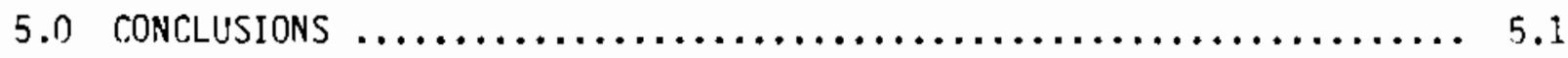

5.1 CONCLUSIONS ON WIND ANO PHOTOVOLTAIC SYSTEMS $\ldots \ldots \ldots \ldots \ldots \ldots .5 .1$

$5 . ?$ IMPLICATIONS FOR SOLAR THERMAL $\ldots \ldots \ldots \ldots \ldots \ldots \ldots \ldots \ldots \ldots \ldots \ldots \ldots$

REFERENCES $\ldots \ldots \ldots \ldots \ldots \ldots \ldots \ldots \ldots \ldots \ldots \ldots \ldots \ldots \ldots \ldots \ldots \ldots \ldots \ldots \ldots \ldots \ldots$ 


\section{FIGURES}

2.1 Distribution of WECS Capacity by System Size $\ldots \ldots \ldots \ldots \ldots \ldots \ldots \ldots$

2.2 Installed WECS Capac ity by System Size $\ldots \ldots \ldots \ldots \ldots \ldots \ldots \ldots \ldots .7$

$? .3$ Financing of U.S. WECS Installations $\ldots \ldots \ldots \ldots \ldots \ldots \ldots \ldots \ldots$

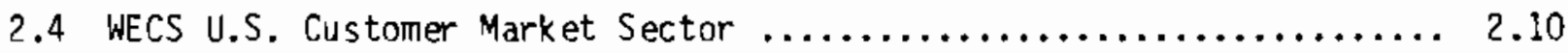

3.1 Distribution of PV Installations by System Size $\ldots \ldots \ldots \ldots \ldots \ldots \ldots . . . .5$

3.2 Installed PV Capac ity by System Size $\ldots \ldots \ldots \ldots \ldots \ldots \ldots \ldots \ldots \ldots \ldots . . .6$

3.3 Financing of U.S. PV Installations $\ldots \ldots \ldots \ldots \ldots \ldots \ldots \ldots \ldots \ldots \ldots \ldots$

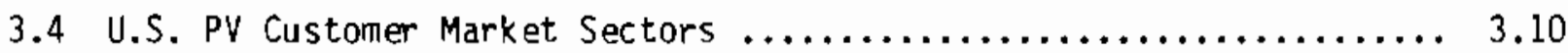

\section{TABLES}

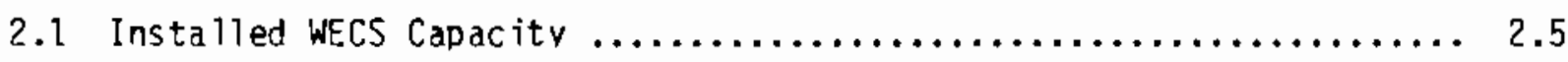

2.2 Installed WECS Capac ity by Systern Size $\ldots \ldots \ldots \ldots \ldots \ldots \ldots \ldots \ldots$

2.3 Average Wind Farm Turbine Size $\ldots \ldots \ldots \ldots \ldots \ldots \ldots \ldots \ldots \ldots \ldots . . \ldots \ldots$

2.4 Government-Funded Large-Scale Wind Machines $\ldots \ldots \ldots \ldots \ldots \ldots \ldots . . .$.

2.5 Wind Farm Installed Costs $\ldots \ldots \ldots \ldots \ldots \ldots \ldots \ldots \ldots \ldots \ldots \ldots \ldots \ldots \ldots$

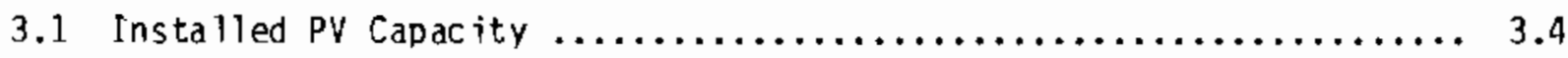

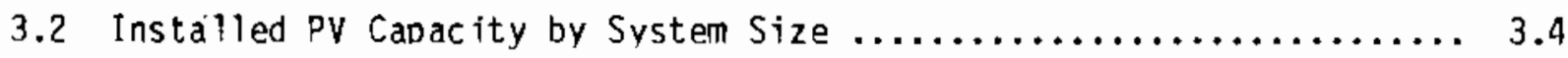

3.3 Sma 11-Sized Custom Systems Funded Through FPuP $\ldots \ldots \ldots \ldots \ldots \ldots \ldots$

3.4 Government-Funded Intermediate-Sized Systems $\ldots \ldots \ldots \ldots \ldots \ldots \ldots \ldots .7$

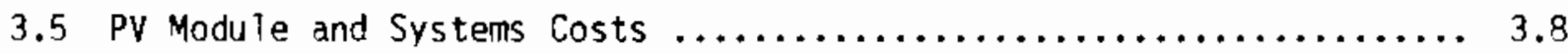




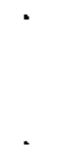




\subsection{INTRODUCTION}

During the earlv 1970 s alternative eneray systems were being studied in on Ty a few laboratories throughout the world. However, the Arab oil embargo of 1973 spurred interest in renewable energy forms, and many nations responded by supporting additional research and development of these systems. This funding, along with the cooperative efforts of government and industry, has helped to launch several alternative energy forms into the commercial marketplace.

Sandia National Laboratory contracted with Pacific Northwest Laboratory to provide information on the developments of nonthermal solar technologies by focusing on the success of wind energy conversion systems (WECS) and photovoltaics (PVS). The information obtained by analyzing the commercial developments of nonthermal solar technologies can provide insight on problems which will need to be addressed by solar thermal technology as it is developed in early commercialization. This report sumarizes the results of this effort by providing detailed information on the installed generating caoacity, market sectors, financing sources, systems costs and warranties of WECS and PV systems (Chapters 2.0 and 3.0). The sales factors that were of primary importance to WECS and PV buyers when they selected their systems are also discussed (Chapter $4.0)$.

A variety of data sources were used to compile information on the commercial status of WECS and PV, including technical literature, industry exoerts, trade associations, state energy offices, as well as systems manufacturers and owners. Information on sales factors was predared by contacting systems owners. 



\subsection{WIND ENERGY CONVERSION SYSTEMS}

Wind energy conversion systems (WECS) were first introduced into the U.S. in the early 1920s. This chapter provides information on the development of wind installations in the U.S., the distribution of wind installations by size, the installed costs of wind turbines over time, the financing of wind installation by funding source, and the ownership patterns of wind installations by market sector.

\subsection{DATA SOURCES}

Various sources were used to compile the information on WECS. Data on installed wind farm capacity were taken from a report prepared by Strategies Unlimited (Dickson, Mckellar and Finch 1984) for the Electric Power Research Institute. That report provides detailed technical and financial information on 105 wind farm installations, mainlv located in California. Strategies Unlimited compiled this information through telephone interviews in mid-1984. At the time of the survey, several wind farm developers had planned to instal? wind farms during the last quarter of 1984. However, several of these planned wind farm developments were not completed. Consequently, the California Public Utilities Commission supplemented Strategies Unlimited's 1984 data by oroviding information on operating wind farms.

Information on government-sponsored and privately owned WECS, as well as systems costs, was obtained through a literature review and contacts with turbine manufacturers and owners, and the American Wind Energy Society.

\subsection{WIND TURBINE HISTORY}

By $200 \mathrm{BC}$ windmills were being used in Persia to grind grain (E)dridge 1975). Most of the earliest wind machines were vertical axis units that used reeds or cloth for sails. The horizontal axis windmills were developed much later and used wooden booms with jib sails. Many of these early machines were used in the Mediterranean, and by the eleventh centurv, windmills were introduced into the Middle East. 
The Dutch improved the basic design of the windmill by replacing the primitive jibs with sails supoorted by wooden bars on both sides of the stock. More modern variations used sheet metal instead of cloth sails and steel stocks. By the fourteenth century, the Dutch had improved the design of the windmi11 to the point where more than 9000 were being used in various industries. The introduction of the steam engine caused a decline in the use of windmills in the Netherlands, and by 1960, only 1000 windmills were in operation.

In the $1920 \mathrm{~s}$ sma11, 1-kWe wind turbines were introduced into the U.S. However, these machines did not capture a large portion of the energy market because the rural electrification drogram was under way at that time. The larqest, early U.S. wind turbine was the Smith-Putnam unit built in the 1940 s. This machine had two blades that weighed a total of 16 tons and produced 1.28 MW. The operation of the machine was discontinued in 1945 when one of the blades broke off near the hub and the unit was not repaired. It was decided that the machine could not compete with the less expensive electricity supplied by conventiona 1 generating olants.

The availability of inexpensive electricity blocked the development of the wind turbine market during the 1940s, '50s, and '60s. It was not unti1 the Arab oil embarqo of 1973 that the wind turbine industry began to develop. This development was assisted by federal funding of wind turbine R\&D provided through the Federal wind Energy Proqram. The goal of this program was to reduce U.S. reliance on imported oil through the development of wind energy. This was accomplished by providina R\&D funding to industry. The program has been successful in supplying vital information on wind resources, aerodynamics and wind turbine design.

A second siqnificant factor in the development of the wind turbine industry was the Public Utilities Requlatory Policies Act (PURPA) of 1978. PURPA reauires electric utilities to purchase electricity from owners of small (less than $80 \mathrm{MW}$ ) renewable energy systems at rates equal to the utility's avoided cost of electricity. Federal and state tax credits and other financial incentives enhanced the economic attractiveness of early wind turbines by reducing the costs of these units relative to conventional energy sources. 
The combination of the Federal Wind Energy Program and PURPA has enabled the wind turbine industry to grow from 5 manufacturers in 1973 to more than 60 manufacturers in 1983 and has enabled installed wind energy capacity to increase from a few MW in 1980 to more than 550 MW in 1984.

\subsection{FEDERAL SUPPORT OF WECS}

The Federal Wind Eneray Program was in itiated in the early 1970s under the direction of the National Science Foundation. In 1974 the program was combined with a national proaram to develop solar technologies under the Energy Research and Development Administration (ERDA). Program responsibilities were shifted to the Department of Enerqy (DOE) in 1977.

The Federal Wind Energy Program is managed by the Wind Energy Technology Division, which is part of the Office of Solar Electric Technologies under the Secretary for Conservation and Renewable Energy. The goals of the program are as follows:

- to estabTish and implement program priorities

- to provide policy and budget guidelines to field laboratories

- to review and approve annual operating plans of the laboratories

- to monitor R\&D

- to represent the U.S. at research and development meetings

- to respond to DOE management and Congressional requests

- to encourage and support technology transfer activities to industry.

The Federal Wind Energy Program was aimed towards engineering development rather than towards conducting basic research on wind turbines. It was felt that the aircraft industry could provide the needed technology base for wind turbine development. Dne of the early developments of the program was the construction and operation of several large wind turbines.

The program was also responsible for improving small wind turbines through activities at a test facility near Golden, Colorado. To date, the Center has tested over 23 commercial wind turbines, many of which are now installed on wind farms. The Center provides this testing service to industry for a fee or on a cooperative basis. 
Engineering develooments achieved under the Federal Wind Energy Program and by industry have led to the construction of lighter, lower cost, and more responsive machines. Data from the construction and operation of wind turbines have increased the understanding of wind characteristics, component construction and systems engineering. The current focus of the program is to support generic research to improve the performance and the reliability of wind turbines. In 1983, research focused on further trving to understand the relationship between the wind turbines and the wind, and the aerodynamic performance of wind turbines at low wind speeds. In 1984 the program had a budget of $\$ 31$ milition.

\subsection{WECS CAPACITY}

The installed capacity of WECS in the U.S. has increased from $13 \mathrm{MW}$ in 1981 to $550 \mathrm{MW}$ by the end of 1984 (Table 2.1), representing an average annual growth rate of $250 \%$. Although the growth rate in WECS is expected to continue through 1985, the possible end of the tax credits in December 1985 is expected to reduce the number of new machines installed.

Approximately 95\% of the wind turbines installed in the U.S. are on wind farms located in the Altamont, Tehachapi and San Georgonio regions of California. This area was selected by wind farm developers because of the excellent wind resources, the availability of state tax credits, and the willingness of utilities to accept WECS into their qrids. Another factor contributing to the growth in wind farms has been the desire of wind turbine manufacturers to test their machines in large commercial applications. The availabilitv of state and federal tax credits and revenue payments through PURPA have made wind farms a very attractive testing qround. Since 1981, the wind turbine industry has received vital information about the operation of these units, and the industry has used this information to significantiy improve the turbines' reliability. The cadacity factor of wind turbines installed on wind farms has increased from $8 \%$ in 1981 to $31 \%$ in 1984 .

Foreign wind turbines are also used on U.S. wind farms. In particular, Danish-made machines have proven to be extremely reliable and generally tend to require much less maintenance than the U.S.-made units. The lower maintenance 
TABLE 2.1 Installed WECS Capacity

$\begin{array}{ccc}\frac{\text { Year }}{1981} & \text { Added Capacity (MW) } & \text { Total Capacity (MW) } \\ 1982 & 13.0 & 13.0 \\ 1983 & 83.4 & 96.4 \\ 1984 & 199.8 & 296.2 \\ & 254.5 & 550.7\end{array}$

and higher reliability of the Danish machines can be partially attributed to the mandatory, one-year testing program sponsored by that government and required of all Danish wind machines before they are olaced on the market.

WECS installations range in size from a few $\mathrm{kW}$, for single turbine installation, to more than $40 \mathrm{MW}$ for large wind farms (Table 2.2). In recent years, the trend has been towards larger wind farms, and currently, most WECS capacity ranges from 10 to $25 \mathrm{MW}$ (Figures 2.1 and 2.2). To date, no wind farms installed are larger than the $80 \mathrm{MW}$ limit set on qualifying facilities by PURPA.

Wind turb ine technology has improved over the past several years, with the average size of individual wind turbines installed in California increasing from $49 \mathrm{~kW}$ in 1981 to $78 \mathrm{~kW}$ in 1984 (Table 2.3).

Although WECS installations in wind farms represent most of the installed capacity, a few large-scale turbines have been installed by the federal govern-

TABLE 2.2. Installed WECS Capacity by System Size

\begin{tabular}{|c|c|c|c|c|c|}
\hline \multicolumn{6}{|l|}{ System } \\
\hline Size (kW) & 1981 & 1982 & 1983 & 1984 & Tota \\
\hline $0-99$ & 5.0 & 5.0 & 5.0 & 5.0 & 20 \\
\hline $100-999$ & 4.9 & 5.2 & 7.2 & 4.0 & 20.3 \\
\hline $1000-9999$ & 3.1 & 41.8 & 52.7 & 26.9 & 124.5 \\
\hline $10,000-24,999$ & 0 & 31.4 & 87.9 & 159.0 & 278.3 \\
\hline$>24,999$ & 0 & 0 & 47.0 & 59.6 & 106.6 \\
\hline Total & 13.0 & 83.4 & 199.8 & 254.5 & 550.7 \\
\hline
\end{tabular}




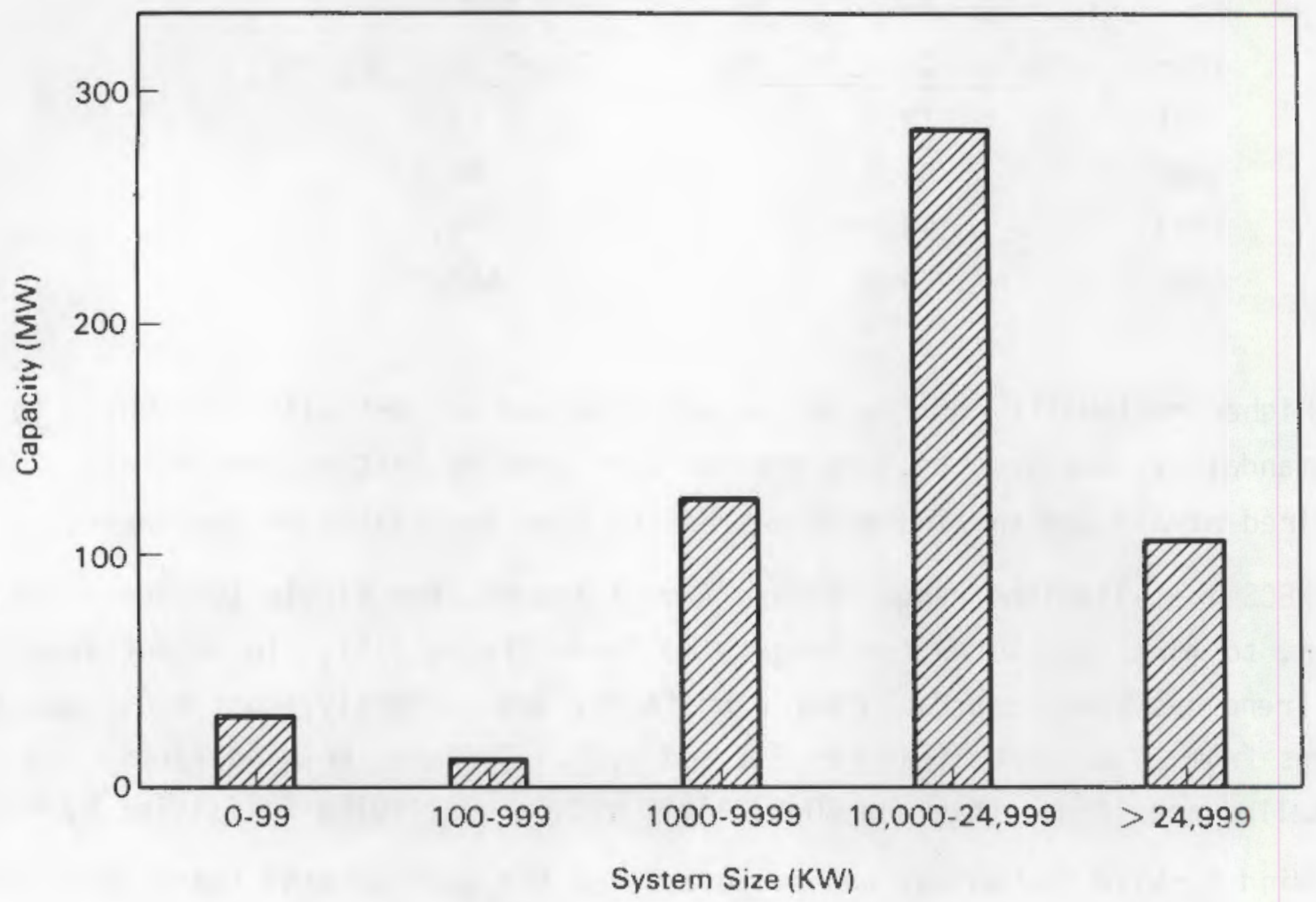

FIGURE 2.1. Distribution of WECS Capacity by System Size

ment (Table 2.4). These installations are part of the Federal Wind Energy Program and they have been built to provide both qovernment and industry with information on the performance of WECS. These machines have been included in the totals in Tables 2.1 and 2.2 because they provide electricity for the utility grid.

The total installed costs of WECS have declined over time in both current and constant dollars (Table 2.5). According to data provided by the California Enerqy Commission, the costs of wind turbines installed in wind farms have decreased from $\$ 3556 / \mathrm{kW}$ in 1981 to $\$ 1860 / \mathrm{kW}$ in 1984 (in constant 1984 dollars; i.e., the effect of differing inflation rates has been removed) (Frank 1985). Installed costs of individual wind turbines have shown a similar decline. As the technologv continues to improve, the installed costs of wind turbines are expected to continue to decline and to become more competitive with energy from conventional sources. 


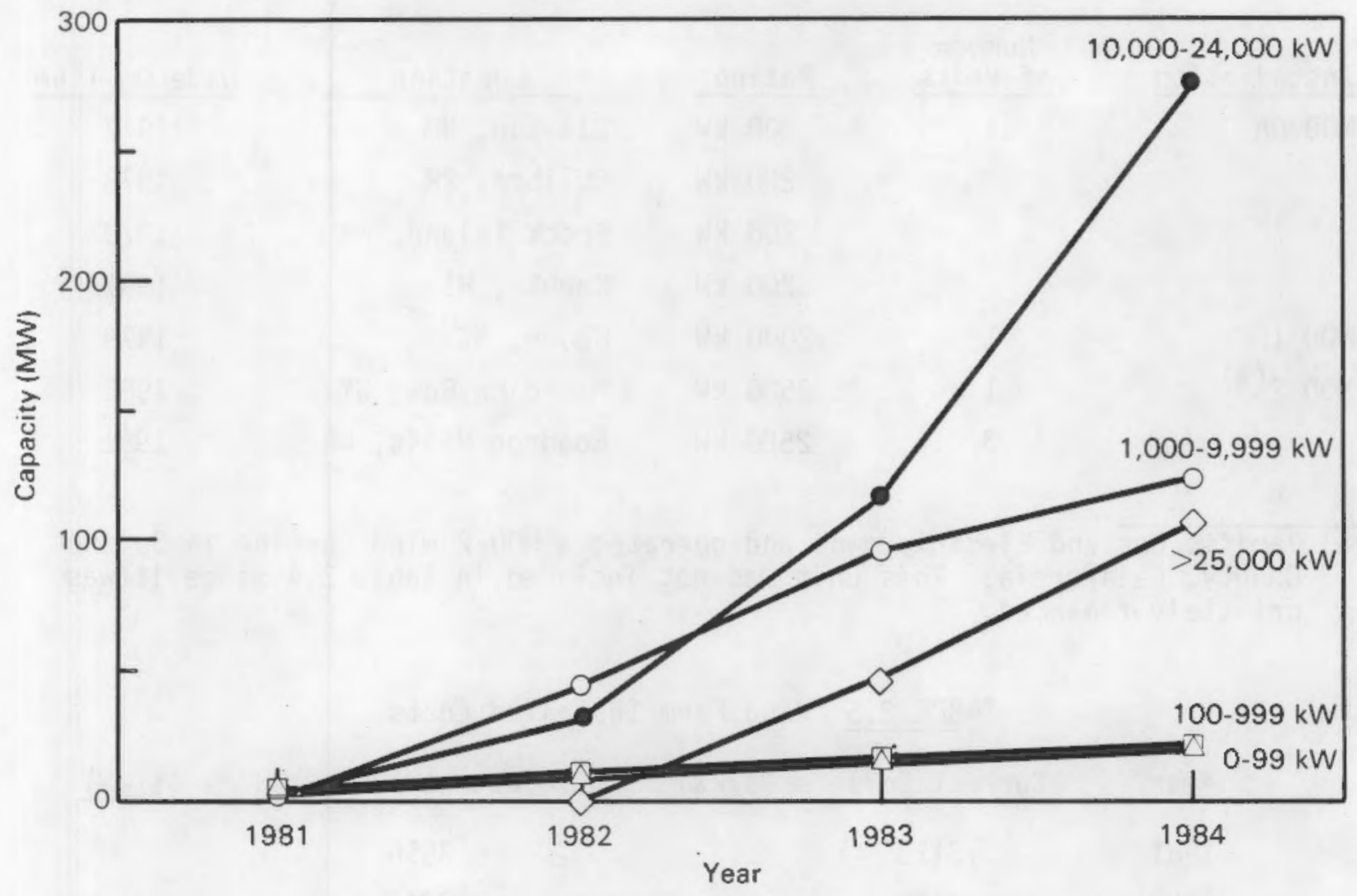

FIGURE 2.2. Installed WECS Capacity by System Size

TABLE 2.3. Average Wind Farm Turbine Size

Year Average Turbine Size (kW)

198149

198256

$1983 \quad 69$

$1984 \quad 78$

\subsection{FINANCING OF WECS INSTALLATIONS}

Alternative energy installations can be financed through one of three basic methods: private financing, third-party financing or government financing. Most small wind installations are owned and financed through private individuals (Figure 2.3) and are primarily single turbine installations located on 
TABLE 2.4. Government-Funded Large-Scale Wind Machines

\begin{tabular}{|c|c|c|c|c|}
\hline Installation & $\begin{array}{c}\text { Number } \\
\text { of Units } \\
\end{array}$ & Rating & Location & Date On-line \\
\hline \multirow[t]{4}{*}{ MOD OA } & \multirow[t]{4}{*}{4} & $200 \mathrm{~kW}$ & Clayton, NM & 1977 \\
\hline & & $200 \mathrm{~kW}$ & Culibra, PR & 1978 \\
\hline & & $200 \mathrm{~kW}$ & Brock Island, NY & 1979 \\
\hline & & $200 \mathrm{~kW}$ & Kahuka, HI & 1981 \\
\hline MOD 1 & 1 & $2000 \mathrm{~kW}$ & Boone, NC & 1979 \\
\hline \multirow[t]{2}{*}{$\operatorname{MOD} 2^{(a)}$} & 1 & $2500 \mathrm{~kW}$ & Medicine Bow, WY & 1982 \\
\hline & 3 & $2500 \mathrm{~kW}$ & Goodnoe Hills, WA & 1981 \\
\hline
\end{tabular}

(a) Pacific Gas and Electric owns and operates a MOD 2 wind turbine in Solano County, California. This unit was not included in Table 2.4 since it was privately financed.

\section{TABLE 2.5 Wind Farm Installed Costs}

$\begin{array}{lcc}\text { Year } & \text { Current Dollars }(\$ / \mathrm{kW}) & \text { Constant 1984 Dollars }(\$ / \mathrm{kW}) \\ 1981 & 3113 & 3556 \\ 1982 & 2175 & 2343 \\ 1983 & 1900 & 1971 \\ 1984 & 1860 & 1860\end{array}$

private 1and. The government-financed installations, listed in Table 2.4, represent about $2 \%$ total installed capacity.

More than $90 \%$ of WECS installations are financed through third-party arrangements. Two of the more popular ownership arrangements used by wind farm developers are limited partnership and Chattel. The limited partnership is a legal arrangement in which all wind turbines are jointly owned, and the business viability of the investment depends upon the collective performance of the turbines. The Chattel arrangement involves an individual or group of individuals who own a specific wind turbine. Therefore, the viability of the investment depends upon the performance of the specific wind turbine. Most wind 


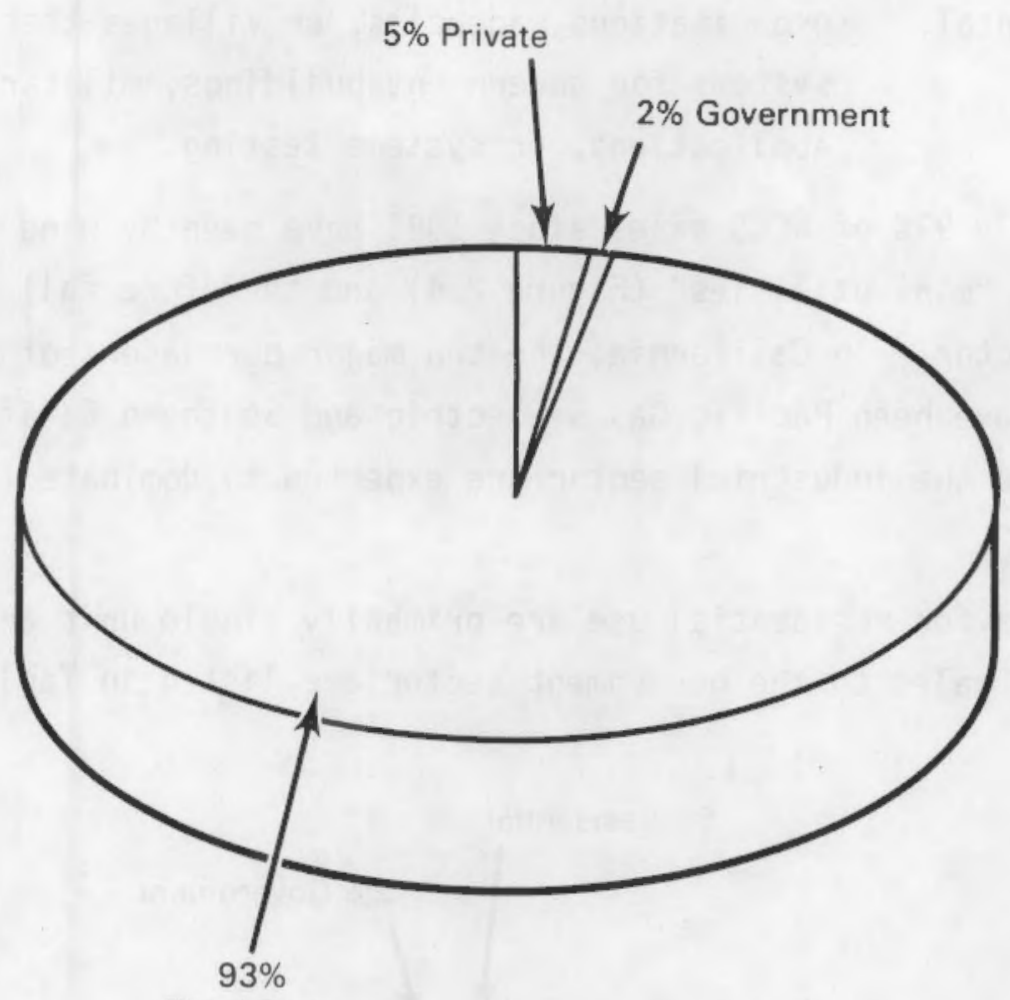

Third Party

FIGURE 2.3. Financing of U.S. WECS Installations (550 MW)

farms in California are limited partnershios because this arrangement spreads the associated risks over a greater number of investors.

\subsection{MARKET SECTORS FOR WECS}

The customer market sectors served by alternative energy systems can be subdivided into the following categories (Watts, Smith and Dirks 1985):

- Residential: individuals who purchase systems for their homes.

- Commercial: individuals or companies who purchase systems to use in a business or to produce power for commercial buildings. This category frequently includes design firms that build systems for other customers.

- Industrial: individuals or organizations who purchase systems for industrial or utility applications. 
- Governmental: organizations, agencies, or villages that purchase systems for government buildings, military applications, or systems testing.

Approximately 93\% of WECS sales since 1981 have been by wind farm developers who act as "mini-utilities" (Figure 2.4) and therefore fall into the industrial market sector. In California, the two major purchasers of power produced by wind farms have been Pacific Gas \& Electric and Southern California Edison. Sales of WECS to the industrial sector are expected to dominate for the next several years.

Again, sales for residential use are primarily single unit and relatively small WECS, and sales to the government sector are listed in Table 2.4.

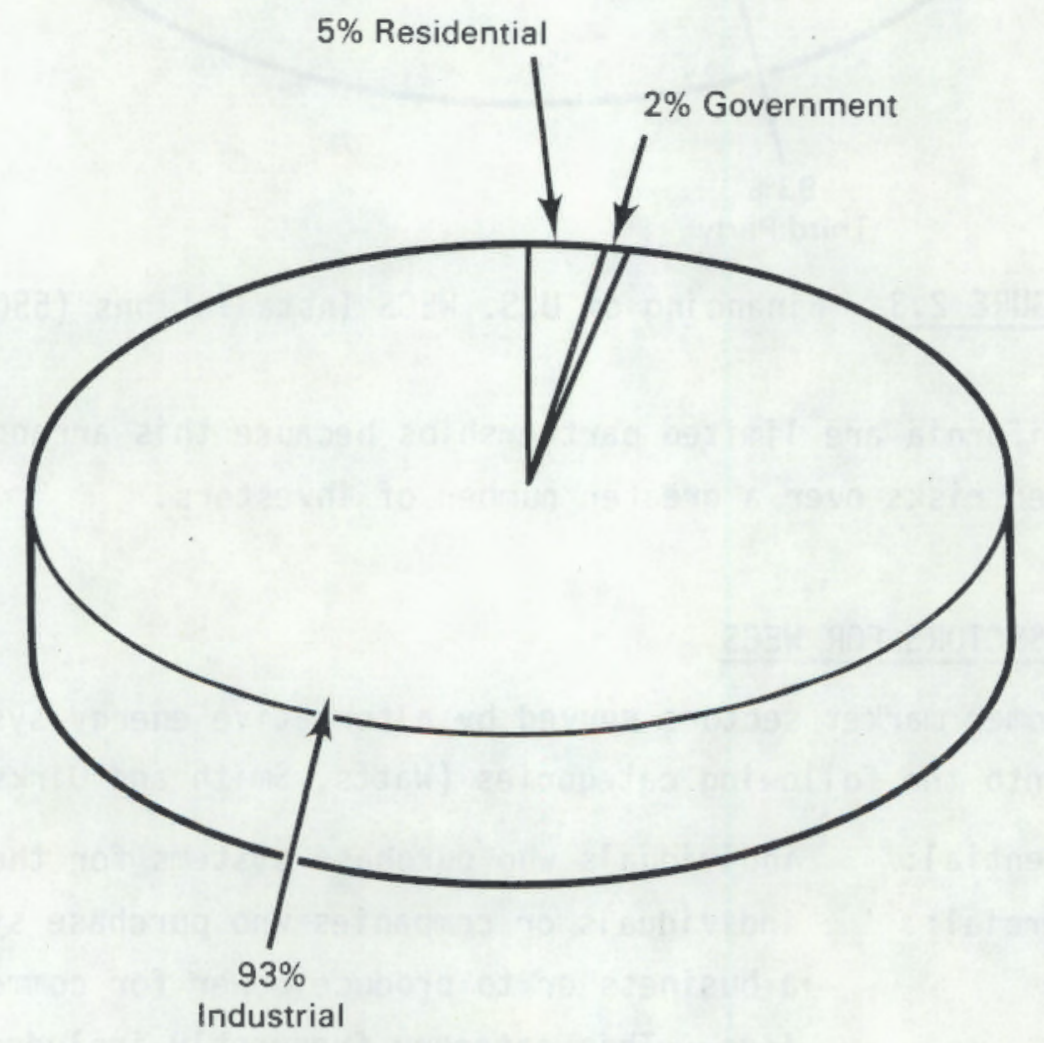

FIGURE 2.4 WECS U.S. Customer Market Sector (550 MW) 


\subsection{WECS WARRANTIES}

Warranties provided by WECS manufacturers typically cover turbine parts and labor and extend for 1 to 3 years. Several WECS manufacturers offer supplemental warranties, or in some cases insurance policies, which are called revenue reimbursement agreements. These contracts state that the WECS manufacturer agrees to reimburse the WECS owner for gross revenue lost if the system is unavailable for more than $10 \%$ of any 12 -month period. The actual amount reimbursed is calculated as the number of kilowatt hours a unit would have produced if it were in service, multiplied by the cents per kilowatt hour paid to the utilitv for power at the time the unit was not in service. To calculate the amount to be reimbursed, the WECS owner must provide the manufacturer with information on wind conditions during the downtime.

Revenue reimbursement agreements are not included in the base price of the wind turbine, and they usually cost $\$ 5000 /$ unit covering a 5-year period. Several manufactuers require WECS owners to also purchase a service agreement ( $\$ 800 /$ unit/yr) with the revenue reimbursement agreement. Frequently, the cost of these aqreements are neqotiated by wind farm developers and turbine manufacturers, and these agreements vary significantly in coverage, costs, and responsibility. 


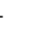




\subsection{PHOTOVOLTAIC SYSTEMS}

The use of photovoltaics (PVS) has grown significantly since they were first used as a oower source for the Vanguard I satellite in the 1950s. Currently, more than $20 \mathrm{MW}$ of PV are installed in the U.S., and much of this success can be attributed to a cooperative industry and government effort.

This chaoter provides information on the development of PVS in the U.S., the distribution of PV installations by size, the installed costs of PV systems over time, the financing of PVs by funding source, and the ownership patterns of PVs by market sector.

\subsection{DATA SOURCES}

Several sources were used to compile the PV sumary statistics, including a literature review, contacts with manufacturers, customers and industry exoerts. Statistics on the distribution of PV-installed capacity by size were developed from data gathered by PNL as part of its work for DOE's Photovoltaics Division (Watts, Smith and Dirks 1985).

\subsection{PV HISTDRY}

The photovoltaic effect was first discovered by the French physicist Edmund Becquerel in 1839 ( $F$ lavin 1982). However, a deeper understanding of this effect was achieved by twentieth century scientists, including Albert Einstein.

Be11 Laboratory scientists tried to imorove the efficiency of the selenium PV cells in the early 1950s. Ouring that time, a second group of Bell scientists was working on electronic devices that were made from silicon. This second team discovered that electricity was produced when the silicon was exposed to sunlight. The two research efforts were merged.

Early selenium PV cells had conversion efficiencies of only $1 \%$, whereas silicon cells had efficiencies of $8 \%$. Other materials were known to have higher theoretical efficiencies than selenium or silicon; however, silicon had the highest laboratory efficiency. Work on developing the silicon PV cell was 
slow because of the availability of cheap oil, larqe fossil fuel plants and nuclear reactors. During the 1950 s silicon cells cost approximately $\$ 600 / W p$ (oeak watt), which was several hundred times the cost of electricity from conventional sources. Because of the excessive costs, Bell Labs shelved the develooment of PV cells.

A renewed interest in PVs began when the space program had a need for a lightweight, long-lasting power supply for satellites. By 1958, silicon solar cells were used on board the Vanquard I satellite. With the assistance of National Aeronautics and Space Administration (NASA), 4 U.S. firms began manufacturing PV cells bv the late 1960s. At the same time, the Soviet Union also began equipping their satellites with PV cells.

During the late 1960 s and earlv 1970s, major technica? achievements improved both the cell conversion efficiencies and the costs of PV cells. However, electricity produced from PV cells still remained almost 50 times more expensive than electricity from conventional energy sources. Therefore, terrestrial PV applications were limited.

The oil embargo of 1973 caused the orice of fossil fuels to rise dramatically and renewed the interest in a1ternative energy sources. European, Japanese, and U.S. qovernments initiated agressive alternative energy research proqrams between 1973 and 1975. As a result, severa 1 comoanies beqan private research on PV cells and several firms began manufacturing sinqle crysta 1 silicon cells for commercial sale. Technical progress continued during the midto-late 1970s, with commercial module efficiencies increasing to $10 \%$ (without concentration) and reliability improving significantly.

Today several hundred companies are involved in the PV industry, with about 60 companies actually manufacturing PV cells and/or modules. Other companies are involved in the design of PV systems, the production of balance of systems comoonents, and the marketing of PV products.

\subsection{FEDERAL SUPPORT OF PHOTOVOLTAICS}

Federal support of PV R\&D began in the early 1970s under the direction of the National Science Foundation. Control of the program activities shifted to 
the Energy Research and Development Administration in 1974 and then to the Department of Energy (DOE) in 1977. Currently, the program is managed by the Photovoltaic Energy Technology Division under DOE's Office of Solar Electric Technologies.

The objective of the federal program is to sponsor high-risk, potentially high-payoff R\&D. The results of this effort provide a technical base for industry. Research is currently focused on developing the following:

- single junction thin films

- high efficiency multijunction concepts

- innovative concepts

- silicon materials

- advanced silicon sheets

- flat plate collectors

- concentrating collectors

- module reliabilitv

- array and balance-of-system improvements

- sustem experiments.

This research effort is being coordinated by the Solar Energy Research Institute, Sandia National Laboratories, and the Jet Propulsion Laboratory, and had a budget of $\$ 50 \mathrm{million}$ in 1984 .

The federal qovernment has also provided other financial mechanisms to assist in developing PVs, including direct grants, low interest loans, direct orocurements, and subsidies to purchasers. The Federal Photovoltaic Utilization Program (FPUP) was created to encourage the direct procurement of PVs for government use. This orogram was initiated in 1977 and was responsibie for the construction of numerous PV installations, including the $100 \mathrm{~kW}$ system at Natural Bridqes National Monument.

\subsection{PV CAPACITY}

The installed generating capacity of PVs has increased from $1.28 \mathrm{MW}$ in 1981 to more than $23 \mathrm{MW}$ by the end of 1984 (Table 3.1). This represents an average annual growth rate of $165 \%$. 
TABLE 3.1. Installed PV Capacity

$\begin{array}{lcc}\text { Year } & \text { Added Capacity (MW) } & \text { Total Capacity (MW) } \\ 1981 & 1.28 & 1.28 \\ 1982 & 3.14 & 4.42 \\ 1983 & 10.66 & 15.08 \\ 1984 & 8.83 & 23.91\end{array}$

Domestic capacity additions increased significantly between 1981 and 1983 . However, the rate of capacity additions declined between 1983 and 1984 because of the decrease in the number of modules installed at a utility-scale installation in Southern California. Also, PV manufacturers were much more successful in marketing their products in non-U.S. countries during 1984 .

The growth in domestic PV capacity is expected to continue through the end of 1985; however, the termination of the federal tax credits is expected to affect the arowth of PV beyond 1985 .

About 50\% of the PV systems installed in the U.S. range from $1 \mathrm{~kW}$ to $1 \mathrm{MW}$ (Table 3.2 and Fiqure 3.1). A more detailed breakdown of systems falling into this intermediate-sized category is difficult to construct because of the lack of detailed information on privately financed PV systems. The $1 \mathrm{~kW}$ to $1 \mathrm{MW}$ categorv primarily includes large residential, commercial, telecominications, some FPIJP-funded systems (Table 3.3), and government-funded, non-FPUP systems (Table 3.4).

A few utility-scale (i.e., l MW) systems are installed in California, including Carrisa Plains, Lugo Station and the Sacramento Municipal Utility

TABLE 3.2. Installed PV Capacity by System Size Svstem Size

\begin{tabular}{|c|c|c|c|c|c|}
\hline$(\mathrm{KW})$ & $\underline{1981}$ & 1982 & 1983 & 1984 & Tota 1 \\
\hline $0-.99$ & .57 & .96 & 1.53 & 2.23 & 5.29 \\
\hline $1-999$ & .71 & 1.18 & 4.93 & 3.30 & 10.12 \\
\hline 999 & 0.00 & 1.00 & 4.20 & 3.30 & 8.50 \\
\hline Total & 1.28 & 3.14 & 10.66 & 8.83 & 23.91 \\
\hline
\end{tabular}




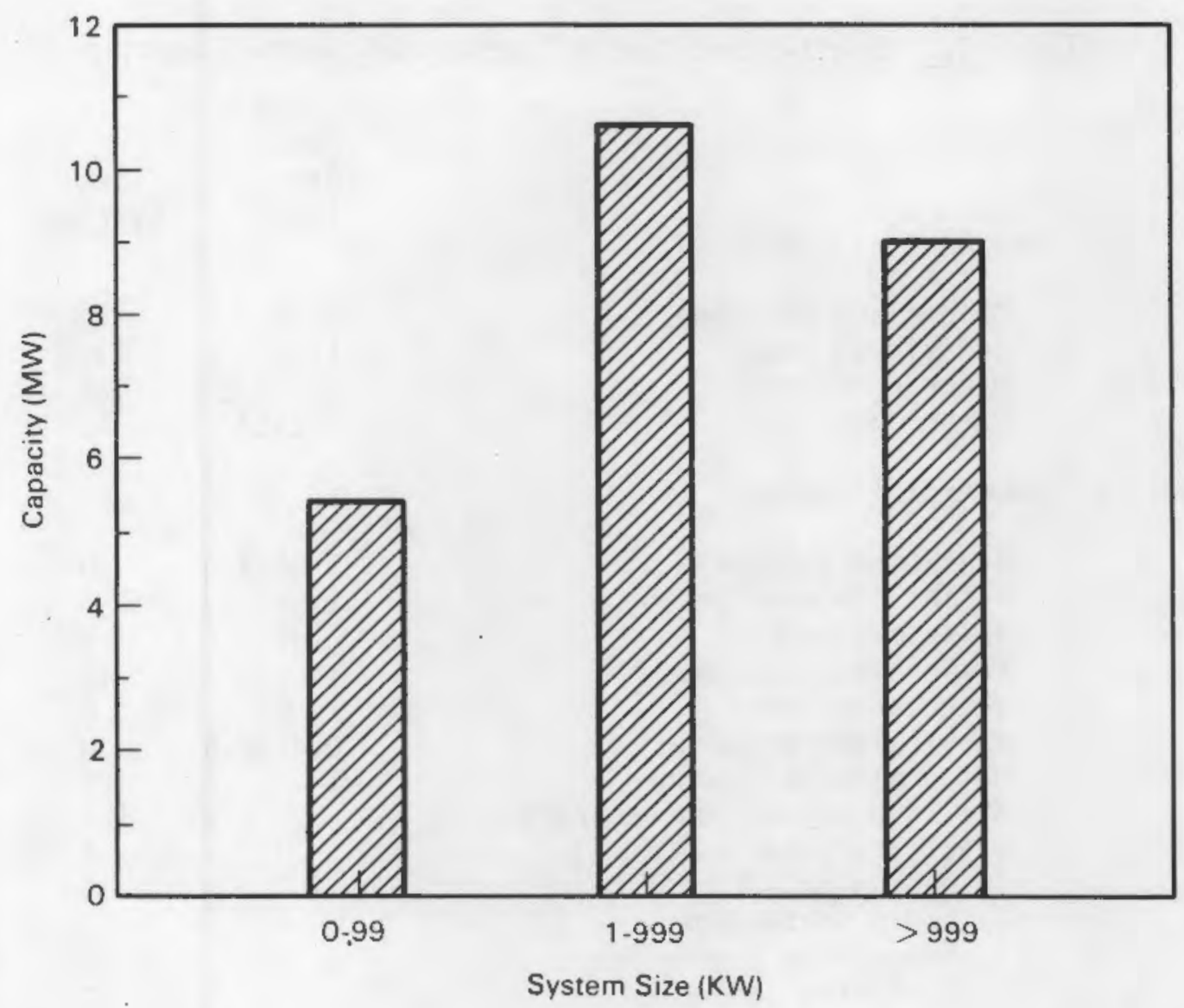

FIGURE 3.1. Distribution of PV Installations by System Size

District (SMUD). Between 1981 and 1984 these systems have shown growth, increasing from $0 \mathrm{MW}$ in 1981 to $8.5 \mathrm{MW}$ in 1984 (Figure 3.2). The remainder of PV installations are less than $1 \mathrm{~kW}$ and are usually remote (i.e., nongridconnected) systems used for residential or agricultural applications.

The expansion of the PV module production and the increased competition from new module manufacturers has helped to reduce the price of PV modules from $\$ 14.00 / \mathrm{Wp}$ in 1981 to $\$ 7.00 / \mathrm{Wp}$ in 1984 (in constant 1984 dollars, based on a purchase of $10 \mathrm{kWp}$ modules) (Table 3.5 ). Additional cost reductions for single crystal silicon cells are unlikely; however, additional cost reductions are expected with expanded production of amorphous silicon and other th in film PV cells. Currently, one U.S. manufacturer is offering an amorphous silicon power module and other U.S. manufacturers are expected to offer similar modules before the end of 1985 . 
TABLE 3.3 Small-Sized Custom Systems Funded Through FPUP

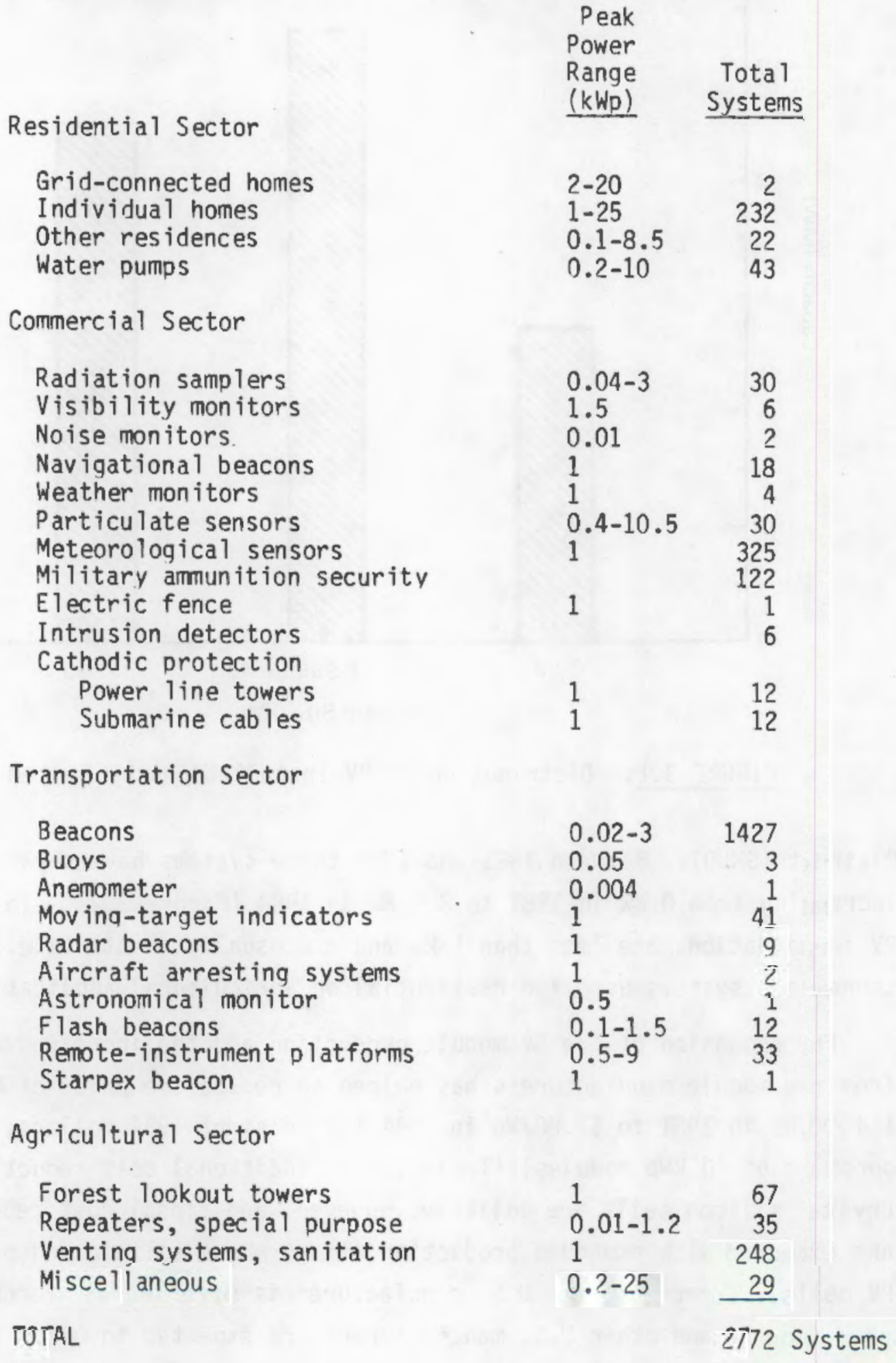


TABLE 3.4 Government-Funded Intermediate-Sized Systems

Location

Peak

Power

Location

$(\mathrm{kW})$

Wilcox Hospital/Acurex

Kauai, Hawai

Sky Harbor Airport/Arizona Public Service

225

Phoenix, Arizona

BDM Corporation

50

Albuquerque, New Mexico

E Systems

Dallas, Texas

Lovington Shopping Center/Lea Country Electric Lovington, New Mexico

100

El Paso Electric/New Mexico State University

El Pasco, Texas

Ok lahoma Center for Science and Arts/

Science Applications, Inc.

Ok lahoma City, Ok lahoma

Beverly High School/Solar Power

Beverly, Massachusetts

San Bernardino Concrete Plant.

San Bernardino, California

WBNO Radio Station

Bryan, Ohio

Irrigation \& Crop Drying

Mead, Nebraska

Air Force Station

Ft. Belvoir, Virginia

College Power System

Mississippi Country Community College

Blvthesville, Arkansas

N.W. Mississippi Junior College

100

Senatobia, Mississippi

Remote Stand Alone Power System

Natural Bridqes National Monument 


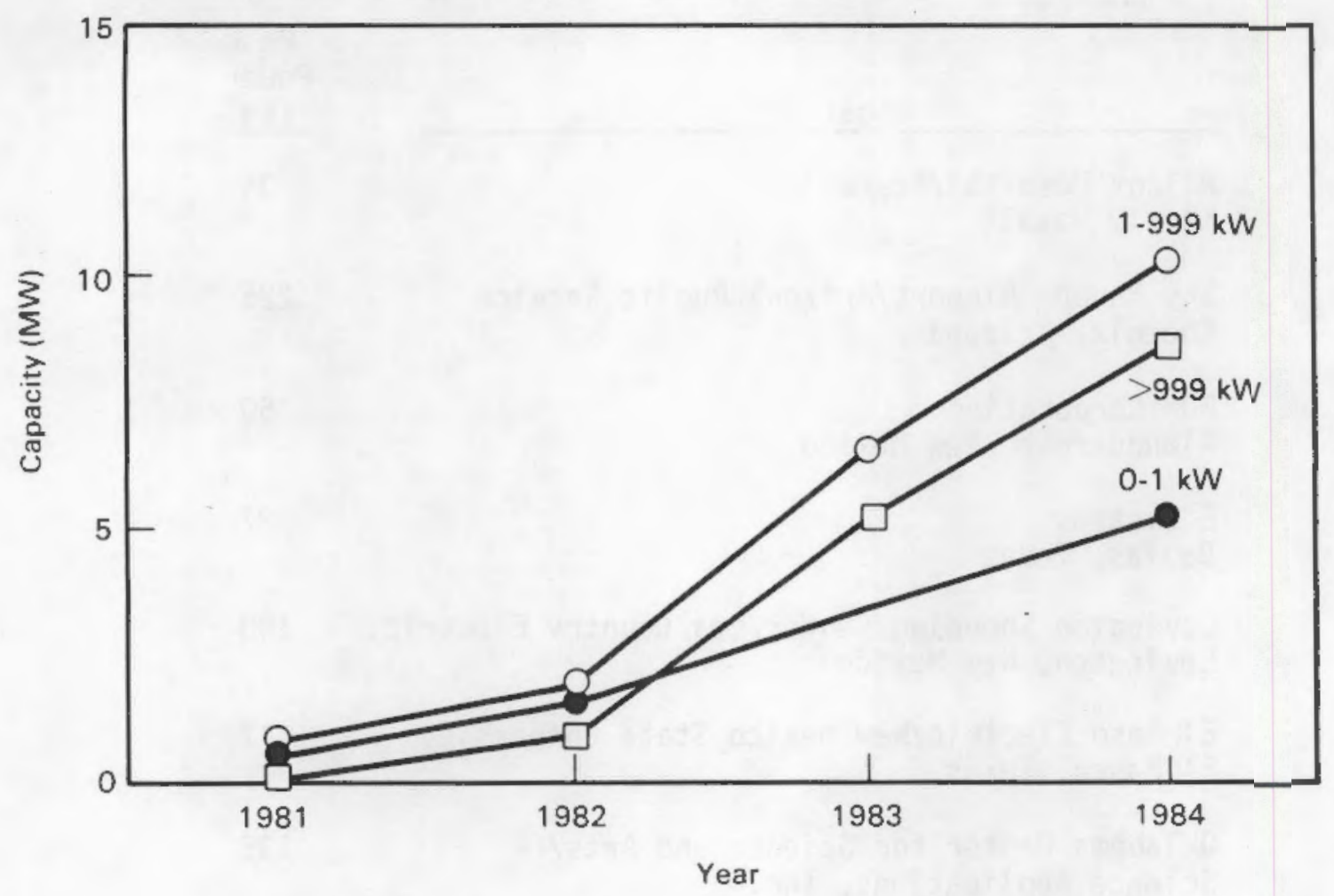

FIGURE 3.2. Installed PV Capacity by System Size

TABLE 3.5. PV Module and Systems Costs

\begin{tabular}{|c|c|c|}
\hline Year & $\begin{array}{l}\text { Module Costs } \\
(\$ / \mathrm{WD}, 1984 \$) \\
\end{array}$ & $\begin{array}{l}\text { Systems Costs } \\
(\$ / \mathrm{Wp}, 1984 \$)\end{array}$ \\
\hline 1981 & 14.00 & 22.30 \\
\hline 1982 & 12.30 & 20.60 \\
\hline 1983 & 9.40 & 18.50 \\
\hline 1984 & 7.00 & 14.00 \\
\hline
\end{tabular}

Depending on the system configuration, PV system costs vary significantly. Table 3.5 shows PV cost estimates in both constant and current dollars. These estimates are based on a PV system that includes the cost of $10 \mathrm{kWp}$ of modules, a DC-to-AC inverter, battery storage (about 5 hours of storage capacity), charge controller, and labor to install the system. These systems costs do not include federal or state tax credits. The city of Dixon, California, recently installed a $20 \mathrm{kWp}$ system (without battery storage) at a cost of $\$ 10.00 / \mathrm{Wp}$. 


\subsection{FINANCING PV INSTALLATIONS}

Approximately $53 \%$ of installed PV capacity (i.e., of $23 \mathrm{MW}$ ) has been financed through some form of third-party arrangements (Figure 3.3). Two major installations, Carrisa Plains and Lugo Station, represent about $50 \%$ of the third-party-financed systems. The othèr 50\% are the solar thermal/PV units manufactured by United Energy Corooration (UEC) and installed at "Solar Farms" in Borrego Springs and Davis, California. These units are rated at $2.5 \mathrm{kWp}$ and are also capable of producing 40,000 Btu of hot water per hour.

Government-financed systems include the FPUP and intermediate-sized government-funded systems listed in Tables 3.3 and 3.4, respectively. The Georgetown University and SMUD installations are also included under government-financed units even though a large portion of these systems were privately financed.

Privately financed PV systems represent about $6.1 \mathrm{MW}$ or $25 \%$ of total installed capacitv and include residential, water pumping and PV module shipments to PV design houses.

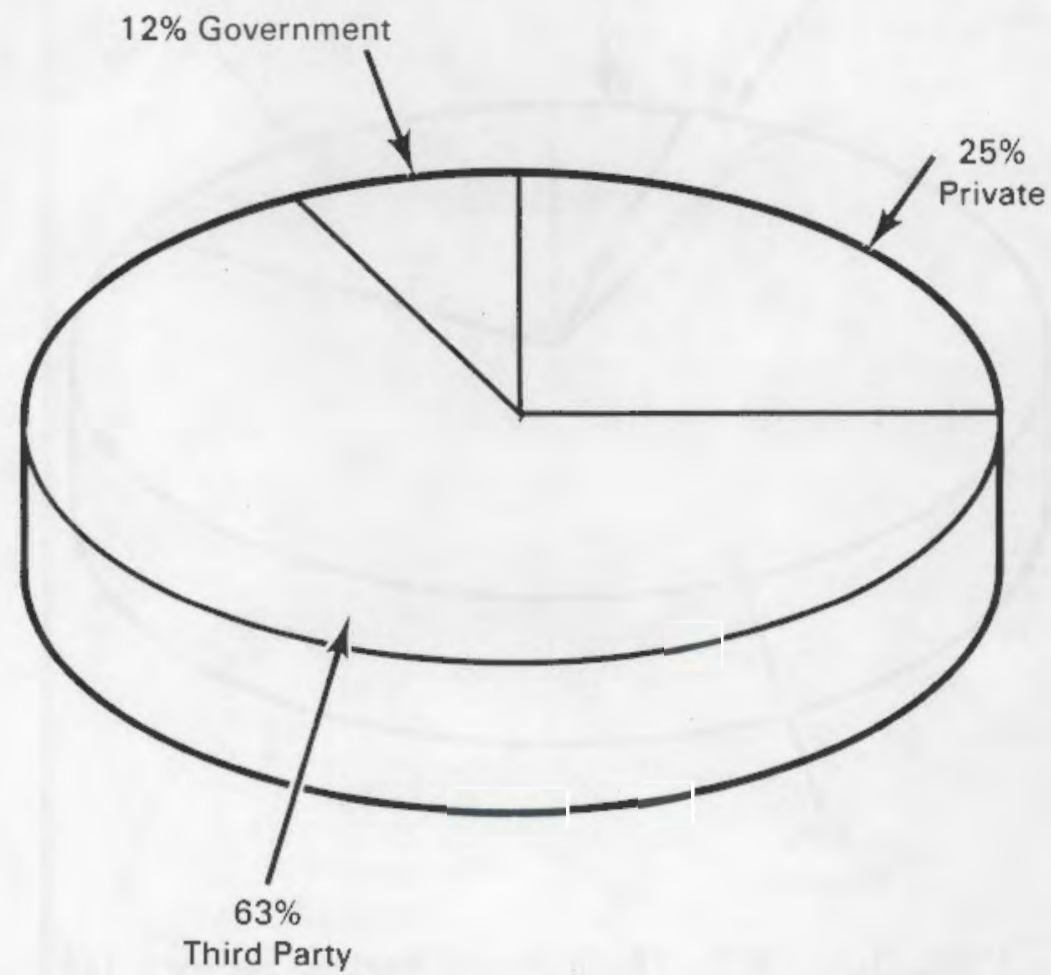

FIGURE 3.3. Financing of U.S. PV Installations (24 MW) 


\subsection{MARKET SECTORS OF PV SYSTEMS}

The customer market sector categories used to classify PV systems are the same as those discussed in Section ?.5 for WECS. The largest customer market sector for PV systems has been the industrial sector, using more than $67 \%$ of installed PV capacity (Figure 3.4). The major installations in this category are Carrisa Plains, Lugo Station and SMUD. This market sector is not expected to grow very rapidly over the next several years because only minor additions are planned for Carrisa Plains and Lugo Station, and additions by SMUD have been postponed.

The commercial market sector accounts for $21 \%$ of installed PV capacity. This sector includes large PV systems, such as the $300 \mathrm{~kW}$ Georgetown University installation, and intermediate-sized systems such as the $10 \mathrm{~kW} \mathrm{McDonald's}$

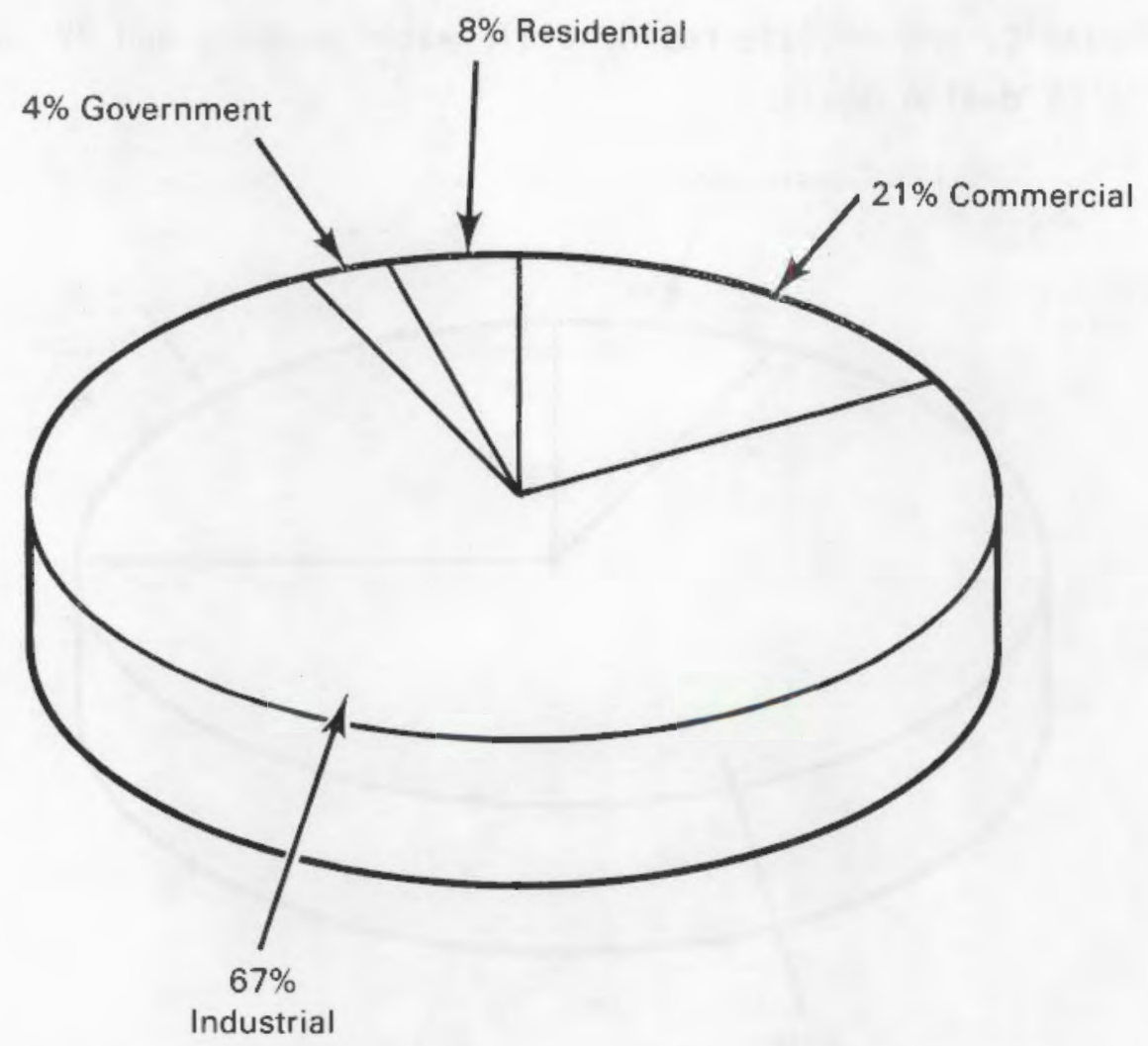

FIGURE 3.4. U.S. PV Customer Market Sectors (24 MW) 
restaurant installation design in AThambra, California. Shipments of PV modules and systems to design houses are also included in this market sector.

The residential market sector represents about $8 \%$ of installed PV capacitv. This sector includes grid and nongrid-connected residences as well as PV systems installed on trailers, recreational vehicles and boats. Most of these systems are less than $1 \mathrm{kw}$.

The qovernment uses about $4 \%$ of installed PV capacity. The primary use of these systems is to power remote communications systems. Most are purchased by the military.

\subsection{PV WARRANTIES}

PV manufacturers provide at least a 1-year warranty that the module will be free from defects. Some manufacturers also guarantee that the combany will replace or repair the module if the power loss which occurs is greater than $10 \%$ of the specified module output. In those cases, the loss of power must be attributed to defects in materials or workmanship. The power guarantee usia $11 \mathrm{v}$ extends for 1 to 5 years from the shipment date; however, 1 PV manufacturer has extender this provision to 10 vears on a few of its modules.

Recently, a PV system developer has specified in a request for proposals that qualifying $P V$ manufacturers provide a 10-year service agreement, a 10-year warrantv, and a guarantee that the $\mathrm{PV}, 190 \mathrm{kWp}$ systern will provide 350,000 $\mathrm{kWh} /$ year (PV News 1985). If the PV svstem fails to meet the quaranteed eneray leve?, the PV manufacturer will be responsible for paying for the electricity purchased to make up the deficit. This type of customer-specified warranty is occurring more frequently in the PV industry. 



\subsection{SALES FACTORS}

The decision to install a wind or PV system requires the consumer to make two decisions: to choose an alternative energy source over conventiona? sources and to choose between the alternative energy technologies. Many factors affect the selection of an energy form; however, the consumer tyoically has some eneray need to meet with in a certain budget. The consumer typically will investigate the possible energy alternatives by looking for characteristics (includina cost) that best meet that need.

This chapter identifies the sales factors that were of primary importance to WECS and PV owners when they selected their particular systems. This information was obtained by interviewing 5 PV and 5 WECS owners. Each was asked to describe his/her svstem, its performance, the primary sales factors considered, and olans for expanding the system.

Because wind farms account for over $95 \%$ of the installed WECS capacity in the U.S., a 11 contacts made for information on sales factors were with wind farm developers. Wind farms investigated included:

- Liberty Park

- Flowind Partners

- Victory Gardens

- Buckeye Wind Farms and California Wind Energy Systems

- Altamont Wind Farm Developer.

Svstem size, configuration and end use vary more widely with PV installations than with WECS. Therefore, the PV systems examined were chosen to reflect this variety. PV svstems investigated were:

- Photocomm, McDonald's Restaurant

- Fresno, California, water oumpina system

- Sacramento Municidal Utility District

- Georqetown University

- Bleicken home. 
Although the systems selected are not a statistically significant sampling of installed WECS and PV capacity, an attempt was made to contact owners of systems that represented the distribution of PV and WECS installed in the U.S.

\subsection{WECS SALES FACTORS}

The sales factors considered by consumers in choosing a WECS for the five wind farms investigated are discussed below for each farm.

\subsubsection{Liberty Wind Park}

Libertv Wind Park, built in June 198?, is a 4-MW wind farm located in Tehachapi, California. The system consists of eighty 50-kW machines, and the electricity produced is fed into the Southern California Edison grid.

Wind turbines were selected by this developer based on the costs of WECS compared with other alternative energy systems. The land required to produce a qiven level of power is significantly less for WECS than it is for other aiternative energy forms because the land surrounding a wind turbine can be used for farming or for grazing. With the relatively high land costs in Southern California, wind turbines became the most economically attractive choice.

This system has not performed to the developer's expectations over the past few vears. Soon after the turbines were installed, the wind turbine manufacturer left the industry. When the wind turbines at the Liberty Park site began to fail, the developer was forced to repair the machines himself. At one point, all of the wind turbines were inoperab?e because of mechanical failure. Since then, the develoder has rebuilt the machines, and to date about $1 \mathrm{MW}$ is back on line. The remaining $3 \mathrm{MW}$ will also be re-installed as soon as the units have been rebuilt.

\subsubsection{Flowind Partners}

Flowind Partners has developed 4 wind farms in the Tehachapi and Altamont, California areas. The farms have an installed capacity of more than 15 MW. The wind turbines installed were manufactured by the park developer and are vertical ax is machines on 17 meter towers. The electricity produced is sold to Pacific Gas and Electric. 
The parent company of Flowind has extensive experience in aerodynamics and, based on this experience, decided to enter the wind industry as a manufacturer and as a wind farm developer. After making the decision, they investigated other alternative eneray forms and felt that WECS were the most economically viable option. The wind farm also provides an opportunity for the company to study the performance of their wind turbines in a commercial operation.

The systems installed at these wind parks have operated to the manufacturer's expectations after a few problems during the start-up phase. Maintenance on the svstems consists of greasing the bearings, changing the $0 i 1$ and checking quv wire tension. However, the systems have been operating unattended for some time.

\subsubsection{Victory Gardens}

The Victorv Gardens wind park consists of 4 installations from 1 Danish and 2 U.S. turbine manufacturers. The turbines came on line during 1981-1984 with a total installed capacity of $40 \mathrm{MW}$. Again, the primarv reason for selecting wind turbines was their economic attractiveness when compared with other alternative energy forms. The developer had considered installing other renewable systems; however, WECS allowed the developer to install a greater number of $\mathrm{kW}$ for a given area of land.

The wind turbines have performed to the developers' expectations, and all machines have required minimal maintenance ( $i . e$. , greasing bearings and inspecting the units). The Danish machines have required less maintenance than the 1J.S.-built units. The developer olans to continue to develop additional wind farms and to investigate the possibility of installing other alternative energy forms.

\subsubsection{Buckeye Wind Farms and California Wind Energy Systems}

Several large wind farms have been developed in the Altamont and Boulevard, California area, including the Buckeye and California Wind Energv Systems (CWES) installations. These wind farms had a total installed capacity of $40 \mathrm{MW}$ at the end of 1984; the electricity produced is sold to San Diego Gas and Electric (from the Boulevard site) and to Pacific Gas and Electric utilities (from the Altamont sites). 
Both hydroelectric and cogeneration systems were evaluated by the developer before wind turbines were selected for the Buckeye wind farm. The principal reason for selecting these turbines was the relative ease of establishing a wind farm compared with other technology ontions. Wind farm developers receive support from the Public Utilities Commission (PUC) and financial incentives from the Federal and California state tax credit and PURPA. Reduced licensing requirements of wind farms over fossil-fueled or nuclear plants, and the enhanced financial atmosphere made WECS the preferred technology.

A variety of machines are installed at these wind farms and most are still on-line; however the machines have not performed to the developer's expectations. Danish-made wind machines are installed at two of the CWES sites, and these units are performing quite we11. All maintenance is performed by the wind turbine manufacturers.

\subsubsection{Altamont Wind Farm Developers}

This developer has established two wind farms in Altamont, California, with an installed capacity of $17.9 \mathrm{MW}$. These farms are composed of various imported wind turbines, and the electricity produced is sold to Pacific Gas and Electric.

This developer has been involved in several cogeneration systems, such as ethanol plants, and the decision was made to construct a wind farm based on the profit potential of these farms. Other alternative energy forms, such as PVs and solar thermal had been considered but were not viewed as being as economically attractive as wind turbines.

The wind turbines installed did not operate to the developer's expectations and major revisions to the machines were required. However, reoair work was covered under the manufacturer's warranty, and once the turbine blades were replaced, machine performance improved significantly.

\section{4.? PV SALES FACTORS}

The sales factors considered by consumers in choosing PVs are discussed below for each system examined. 


\section{4.?.1 Sacramento Municioal Utility District}

The Sacramento Municidal UtiTitv District (SMUD) installed a 1 MW PV svstem in 1984. This system consists of various PV modules manufactured by several U.S. PV manufacturers, a sing Te axis tracking system, and synchronous inverters. A small computer system has also been installed to monitor the performance of the sustem and to control array tracking.

The demand for electricity in the Sacramento area has been increasing in recent vears, and it became apparent that additional generating capacity would be needed in the near future. The peak demand for the utility's electricity comes from the tremendous air conditioning loars that occur mid afternoon to early evening. A PV system was selected after considering both conventional and other alternative enerqv options, primarily because it had fewer licensing requirements than fossil-fueled or nuclear olants, it synchronize well with SMUD's peak load requirements, and it should run unattended after the start-up phase.

Currently, SMUD is installing a second MW of PV arrays that are expected to come on-line by the end of 1985. However, SMUD is not expected to expand its PV sustem beyond $2 \mathrm{~ms}$.

\section{4.?.2 McDonald's Restaurant}

A 10-kW, arid-connected PV system was installed on a McDonald's franchise in Alhambra, California, in 1984. This system was purchased by a group of orivate investors who received the energy tax credits for the system. The system was installed on the roof of the McDonald's franchise, and the power was sold to the restaurant at a rate that is $20 \%$ less than that currently being charged by the utility. The system provides electricity for the restaurant, and the excess is sold back to the utility.

The franchise installed a PV system on their roof because they were interested in finding an inexpensive and reliable energy source. This oarticular system was well suited to their needs because it was third-party financed, and the franchise was able to purchase the electricity at a discount. The system has operated well since its installation in 1984 and has required little maintenance. 


\section{4.?.3 PV Water Pumping}

A private landowner installed a 384-W water-pumping system on his farm outside Fresno, California, in 1982. This systen is powered by 12 PV modules and has a DC oump to draw well water for irrigating 4 acres of farm land. No inverter is used on this system because it is not connected to the utility grid.

The owner chose a PV system primarily because the system's cost was significantly less than other alternative. With the increased utility rates and the availability of tax credits, the owner estimates that the system will pay for itself in 3 to 4 vears (when considering the costs of connecting to the utility grid). Other alternative energy sources were also considered, including wind (Door resource at his site) and solar thermal (deemed not reliable).

The system has ooerated well since it was first installed in 1982 and has required very little maintenance. The owner has been very pleased with this system and is planning to install PV modules on his home in the near future.

\subsubsection{Georaetown University}

Georgetown University has installed a $300-k W$ PV system on the roof of their University Center. This system is grid-connected and provides electricity for the faculty lounge and a few classrooms. Excess electricity is sold back to the utility.

The University chose PVS primarily because it is striving towards energy independence. Since the early 1970s, the University has been reducing its dependence on oil by installing a fluidized bed coal system and by investiqating the possibility of integrating an alternative energy option into its power plant.

The PV system has performed quite well and has required a minimum amount of maintenance. A 1-year warranty was negotiated into the original contract with the systems integrator, so any oroblems arising will be resolved quick?y.

\section{4.?.5 Kurt B? eicken}

In 1977 Kurt Bleicken purchased a PV system to provide electricity for his home and business. The $80-4$ system consists of sixteen $50-W$ modules, an inverter, and eight 6-volt storage batteries. Power produced by the system is used 
to operate lights, appliances, and a computer. Excess electricity produced during the day is stored in a battery bank for use during non-daylight hours or on overcast days.

The home and business are located on 21 acres of land three-fourths of a mile from the closest power line. At the time Bleicken was considering purchasing the acreage, similar Tand with arid power was selling for about 3 times the cost of off-arid land. Also, the cost of connecting to the nearest power line was $\$ 12,000$ to $\$ 15,000$. The decision was made to purchase the land and to investigate the use of alternative energy source.

Several options were considered before a PV svstem was selected; wind turbines were viewed as a possibility, but local wind resource was marginal and, at the time, the reliability of wind machines was Door. A PV system was finally selected because of its high reliability and low maintenance. To date, no major prob? ems have been encountered and no significant changes in lifestyle have been required. 
. 


\subsection{CONCLUSIONS}

This chapter surmarizes the data presented on installed WECS and PV generating capacity. The potential implications of the study's results for the development of solar therma? electric systems are also discussed.

\subsection{CONCLUSIONS ON WINO AND PHOTOVOLTAIC SYSTEMS}

During the early 1980s, both WECS and PVs have experienced a strong growth in installed capacity. By the end of 1984, wind systems had an installed capacity of over $550 \mathrm{MW}$, while PV systems had an installed capacity of about 24 MW. This level of installed capacity is composed of thousands of wind turbines and PV modules.

The industrial sector (wind farms) has been the dominant market for WECS, accounting for $93 \%$ of installed wind capacity. For PV systems, the market has been much more diverse, with $67 \%$ of total installed capacity installed in industrial applications, $21 \%$ in commercial applications, $8 \%$ in residential applications, and $4 \%$ in government apolications.

Third-party financing is used for all of the industrial sector wind investments, accounting for $93 \%$ of the installed wind capacity. PV systems show more varietv in financing, with third-party financing being used for $63 \%$ of the installed capacity, private financing used for $25 \%$ of the installed capacity, and government-related financina used for $12 \%$ of the installed capacity.

Although only a few system owners were contacted as part of this study, the contacts did indicate the important sales factors for wind and PV systems. The results of these contacts indicate that wind farm deveTpers are driven primarily by the desire for an economically attractive investment and are concerned with system reliability and initial capital cost. California offers a verv attractive environment for wind system installations because of the generous state tax credits, a helpful Public Utility Commission, and an adequate wind resource. One of the on lv drawbacks mentioned with locating energy parks in California is the high cost of land; however, this has not proven to be a major problem for wind farms because of their relatively small land requirements. 
Wind farms are also attractive to wind turbine manufacturers. The installations are both excellent business opportunities and provide testing grounds for learning more about the operation and reliability of the manufacturers' machines. This information has been Daramount in helping U.S. manufacturers build units that require less routine maintenance and have fewer breakdowns.

Dwners of PV svstems indicated a greater variety of reasons than WECS owners for selecting their particular systems. Most owners noted that PVs were considered to be the most economicallv attractive choice qiven their particular needs and available alternatives. A PV system is frequentiy chosen for use in nongrid-connecter applications, when the owner's alternative is to Day the costs of connecting to the utility arid. However, PVs can also be attractive when considering the costs of licensing fossil fuel or nuclear systems.

A second factor frequently mentioned was the reliability of PV systems and their Tow maintenance requirements. In general, PV systems operate well unattended, an attractive feature for both arid and nonqrid-connected applications. Owners tvoicallv do not want an eneray system that requires constant attention and a high deqree of mechanical capability. They prefer systems that operate indedendent $1 y$, that save money, and that provide the same quality of life as grid power.

Modularitv (the capability to increase capacitv in small increments) was not explicitly mentioned as a sales factor for either wind or PV systems, although it appears clear that it may be implicitly important to the success of both technologies. The modular nature of wind turbines makes it feasible to begin wind farm development with several megawatts and easily expand capacity over time. This feature allows someone to begin a large project without having the total project financing committed. For PV svstems, the important aspect of modularity seems to be more the capability to construct very small systems rather than expanding existing systems. As shown by the data on PV system averaqe size, a large part of the PV market to date clearly has been in specialized apolications that have required small system sizes. 


\subsection{IMPLICATIONS FOR SOLAR THERMAL TECHNOLOGY}

While this study did not exolicitly address development issues for solar thermal technologv, severat potential imblications can be identified based on the experience of wind and PV svstems. These implications should be regarded as tentative until a more detailed analysis can be conducted of the issues specifically from a solar thermal perspective.

For solar thermal electric systems that are grid-connected (with power sold to or used by the utilitv), a prerequisite is that the economic returns for those systems be equal to those for other technoloqies. Also, reliability of the svstems and the amount of operating experience with the systems most likely will be key concerns for owners. Thousands of PV systems and individual wind turhines have been installed and can be used to judqe and improve system reliability. Until reliability and operating requirements for solar thermal systems can be judged by investors with the same confidence as for other energy systems, most likely a risk premium will exist for investments in solar thermal systems.

Based on the experiences of wind and PV systems, early solar thermal plants would likely be third-party owned and financed. Two commercial solar thermal electric svstems constructed to date have verified that assumotion: the SEGS olant, constructed by Luz, and SolarPlant 1, constructed by LaJet. As long as third-party investors receive economic incentives that utilities do not, such as tax credits and accelerated depreciation, utilities will have an economic incentive to contract for power from solar thermal plants. Utility ownershid of solar thermal plants will probably become more imoortant only as institutional changes eliminate incentives designed to stimulate comnercialization of renewable energy systems. Even with the complete ohase out of energy tax credits, some incentive will exist for third-party ownership because of the more rabid plant depreciation compared to utilitv ownership.

The modularity that exists for some solar thermal concepts (such as parabolic dishes with distributed engines) would appear to be of some economic benefit in constructing systems. It is unclear bow modular (the minimum capacity that can economically be added to a plantl the olants should be to capture this 
benefit. The trend in wind farm development has been toward larger systems on the order of tens of MW. The expansion of wind farms seems to be by construction of new farms rather than by gradually adding turbines to existing farms. The limited partnerships financina arrangements used by wind farms would also be apolicable for solar thermal and seem to be a reasonable financing option for solar thermal plants ranging from 10 to $25 \mathrm{MW}$.

Reliable operation with low operation and maintenance costs is a desirable factor for solar thermal plants (or for any plants) that are grid-connected and may be a critical factor for plants that are not grid-connected. Unattended operation and low maintenance were mentioned as imoortant characteristics by all the PV and WECS system owners contacted.

Warranties for equioment performance; including orovisions to provide owners with reimbursement for revenue lost because of equipment downtime, could be an important aspect of solar thermal development. Warranties of different complexity seem to increasingly used for wind and PV systems. For both wind and PV systems, a sinqle company can sell and install the complete system. This situation enhances the capability of the supplier to orovide a complete system warranty. This may be possible for some solar thermal technologies but would appear to be difficult for central receiver plants, where several different companies (concentrator supplier, receiver suppliers, architects and engineers, etc.) would be involved in plant procurement and construction.

While sizes of wind svstems have been increasing over tiime, most of the sytems being built in 1984 ranged from 10 to $25 \mathrm{MW}$. This may be indicative of the current ability to raise capital for alternative energy investments, although there is not sufficient data to rule on this definitively. It is clear that for some reason, wind systems are not being built exclusively at the upper range of the system size allowed under PURPA (80 MW). 


\section{REFERENCES}

Dickson, E. M., M. F. Mckellar and D. 8. Finch, 1984. "Wind Power Stations: 1984 Survey." Strategies Unlimited, Mountain View, California.

Eldridge, F. R. 1975. "Wind Machines." NSF-RA-N-75-051, National Science Foundation, Washington, D.C.

Flavin, C. 1982. "Electricitv from Sunlight: The Future of Photovoltaics." World Watch Paper Number 52, Worldwatch Institute, Washington, D.C.

Frank, A. L. (ed). 1985. "California Adds 366 MWe of Wind Capacity; Size, Capacity Factor Up, Price Down." Solar Energy Intelligence Report, Volume 11. Number 4, p. 30, Business Publishers, Inc., Silver Spring, Maryland.

Maycock, P. (ed.) May 1985. "ARCO Solar Wins $190 \mathrm{KW,} \mathrm{John} \mathrm{Long} \mathrm{Project} \mathrm{with}$ 10-Year Annual Power Guarantee." PV News. 4(11):5.

Photovoltaic News. February 1984, 3(2):3.

Solar Enerqy Research Institute. 1984. Wind Enerqy Systems. SERI/SP-2712647, Solar Energy Research Institute, Golden, Colorado.

Watts, R. L., S. A. Smith and J. A. Dirks. 1985. Photovoltaic Industry Progress Through 1984. PNL-5483, Pacific Northwest Laboratory, Rich Tand, Washinaton. 
. 


\section{DISTRIBUTION}

No. of

Copies

OFFSITE

C. Carwile

U.S. Department of Enerqy

Forresta? Buildina, CE-314

1000 Independence Ave., SW

Washington, D.C. 20585

30 DOE Technical Information Center

H. S. Coleman

U.S. Department of Energy Forrestal Building, CE-314 1000 Independence Ave., SW Wash inqton, D.C. 20585

S. Gronich

U.S. Department of Energy

Forrestal Buildina, CE-314

1000 Independence Ave., SW

Washinaton, D.C. 20585

C. Manqold

U.S. Department of Energy

Forrestal Building, CE-314 1000 Independence Ave., SW Washington, D.C. 20585

F. H. Morse

U.S. Department of Energy

Forrestal Building, CE-3l

1000 Independence Ave., SW

Washington, D.C. 20585

M. R. Scheve

U.S. Department of Enerqy

Forrestal Building, CE-314

1000 Independence Ave., SW

Washington, D.C. 20585

F. W. Wilkins

U.S. Department of Energy

Forrestal Building, CE-3i4

1000 Independence Ave., SW

Washington, D.C. 20585
No. of

Copies

D. Graves

U.S. Department of Energy

Albuquerque Operations

P. 0. Box 5400

Albuquerque, NM 87115

J. Weisiger

U.S. Department of Energy

Albuquerque Operations

P. D. Box 5400

Albuquerque, NM 87115

R. L. Rinne

Sandia National Laboratory

Livermore, CA 94550

A. C. Skinrood, 8471

Sandia National Laboratory

Livermore, CA 94550

L. G. Radosevich, 8471

Sandia National Laboratory

Livermore, CA 94550

H. F. Norris, 8477

Sandia Nationa 1 Laboratory

Livermore, CA 94550

J. C. Swearengen, 8473

Sandia National Laboratory

Livermore, CA 94550

D. B. Dawson, 8473

Sandia Nationa 1 Laboratory

Livermore, CA

W. R. Delameter, 8473

Sandia Nationa 1 Laboratory

Livermore, CA 94550

J. J. I annucci, 8475

Sandia National Laboratory

Livermore, CA 94550 
No. of

Cooies

E. H. Carrel1, 8475

Sandia National Laboratory

Livermore, CA 94550

P. W. Zimmerman, 8475

Sandia Nationa 7 Laboratory

Livermore, CA 94550

Publications Division

Sandia Nationa 1 Laboratory

Livermore, CA 94550

Technical Library Processes Division

Sandia National Laboratory

Livermore, CA 94550

M. A. Pound, 8024

Central Technical Files

Sandia National Laboratorv

Livermore, CA 94550

D. G. Schueler, 6226

Sandia Nationa? Laboratory

P. 0. Box 5800

Albuquerque, NM 87115

J. V. Dtts, 6222

Sandia National Laboratory

P. 0. Box 5800

A ibuquerque, NM 87115

J. H. Leonard, 6227

Sandia Nationa I Laboratory

P. 0. Box 5800

A lbuquerque, NM 87125

B. Gupta

Solar Eneray Research Institute

1617 Co le Bou levard

Golden, CO 80401

A. A. Heckes, 6227

Sandia National Laboratory

P. $0.80 \times 5800$

Albuquerque, NM 87115
No. of

Copies

L. Shannon

Solar Energy Research Institute

1617 Cole Bou levard

Golden, C0 80401

M. Carasso

Solar Energy Research Institute

1617 Cole Boulevard

Golden, CO 80401

ONSITE

DOE Richland Operations Office

K. W. Bracken

22 Pacific Northwest Laboratory

C. H. Bloomster

J. A. Dirks

R. M. Fleischman

S. A. Smith (10)

R. L. Watts

T. A. Williams

Technical Information (MH) (5)

Publishing Coordination (2) 